\title{
BENZODIAZEPINE Ro 15-1788: ELECTROPHYSIOLOGICAL EVIDENCE FOR PARTIAL ACONIST ACTIVITY
}

\author{
JOHN H. SKERRITT and ROBERT L. MACDONALD* \\ Department of Neurology, University of Michigan Medical Center, Ann Arbor, MI 48109 (U.S.A.)
}

(Received September 16th, 1983; Final revised version received and accepted October 24th, 1983)

Key words: GABA receptors - diazepam - anticonvulsant - benzodiazepine antagonists - spinal cord cultures

The effects of diazepam and Ro 15-1788 were assessed upon responses of mouse spinal cord (SC) neurons in cell culture to the amino ac ' neurotransmitters 4-aminobutyric acid (GABA) and S-glutamic acid. Diazepam (100 nM) enhanced GABA responses by $65 \pm 3 \%$ (113 cells), while Ro 15-1788 (100 nM) faiied to alter GABA responses but reduced their enhancement by diazepam. Higher Ro 15-1788 concentrations (1 $\mu \mathrm{M}$ or $10 \mu \mathrm{M})$ enhanced $\mathrm{GABA}$ responses to a moderate extent, while blocking further enhancement of GABA by diazepam. Neither diazepam nor Ro 15-1788 affected glutamate responses or resting membrane potential or conductance of spinal cord neurons. These results provide electrophysiological support for partial agonist, rather than pure antagonist, activity of Ro 15-1788.

The imidazobenzodiazepine Ro 15-1788 (ethyl-8-fluoro-5,6-dihydro-5-methyl-6oxo-4H-imidazo[1,5-a][1,4]benzodiazepine-3-carboxylate) is a potent displacer of benzodiazepine (BZ) binding [6] and has been shown to antagonize the behavioral and electrophysiological actions of diazepam $[1,6,12,18]$ but not anticonvulsants which did not bind to $\mathrm{BZ}$ receptors $[6,12,18]$. Low concentrations of Ro 15-1788 blocked the in vitro enhancement by diazepam of $\left[{ }^{3} \mathrm{H}\right] \mathrm{GABA}$ or $\left[{ }^{3} \mathrm{H}\right]$ muscimol binding to rat brain membranes $[8,17]$.

While initial studies in rodents and humans failed to reveal any intrinsic activity of Ro 15-1788 [4, 6], subsequent behavioral studies have demonstrated apparent partial agonist activity. At high doses, Ro 15-1788 reduced the convulsant activity of pentylenetetrazole, bicuculline and Ro 5-3663 [5, 12,19] and, like diazepam, Ro 15-1788 antagonized the development of amygdaloid kindled seizures in rats [1, 15]. Using drug discrimination techniques, animals generalized the cue for the $\mathrm{BZ}$ agonist chlorazepate to Ro 15-1788 [3]. These behavioral results, while suggesting that Ro 15-1788 has BZ-like activity, do not necessarily confirm that such activity arises from an agonistic effect at $\mathrm{BZ}$ receptors.

*Author for correspendence at: University of Michigan, Neuroscience Laboratory Building, 1103 East Huron, Ann Arbor, MI 48109, U.S.A. 
We have investigated the ef fects of Ro 15-1788 upon GABA responses on mouse spinal cord (SC) neurons in cell culture and the enhancement of such responses by dic.repam. We report that low concentrations of Ro 15-1788 (100 nM) antagonized diazepam enhancement of GABA responses, while higher concentrations $(1 \mu \mathrm{M}$ and $10 \mu \mathrm{M})$ enhanced GABA responses, suggesting that Ro 15-1788 is a partial agonist at $\mathrm{BZ}$ receptors.

Cell cultures were prepared from SCs with attached dorsal root ganglia from 12-14-day-old mouse embryos, as described earlier [11, 14], and SC neurons (5-8 weeks in vitro) were penetrated on the modified stage of an inverted phase-contrast microscope, using high resistance (25-40 MR) glass micropipettes filled with either $4 \mathrm{M}$ potassium acetate $(\mathrm{KAc})$ or $3 \mathrm{M}$ potassium chloride $(\mathrm{KCl})$. Cultures were bathed in a phosphate-buffered saline composition in $\mathrm{mM}: \mathrm{NaCl} 143.4, \mathrm{KCl} 4.2, \mathrm{CaCl}_{2}$ $0.9, \mathrm{MgCl}_{2} 10.0$ and glucose 5.6 in $9.5 \mathrm{mM}$ sodium phosphate buffer at $\mathrm{pH}$ 7.35-7.40), and maintained at $33-34^{\circ} \mathrm{C}$. Using a conventional bridge circuit, simultaneous current injection and membrane potential measurement were made with a single recording micropipette; data were recorded on a 6-channel Gould polygraph.

GABA $(0.5 \mathrm{M}, \mathrm{pH} 3.2)$ or S-glutamate $(0.5 \mathrm{M}, \mathrm{pH} 10.0)$ were applied iontophoretically using $400 \mathrm{~ms}$ rectangular current pulses $(+0.5$ to $+20 \mathrm{nA}$ for GABA, -5 to $-80 \mathrm{nA}$ for S-glutamate) at $4 \mathrm{~s}$ intervals. Diazepam, Ro 15-1788 or vehicle ( $0.1 \%$ or less dimethylsulfoxide) were applied by miniperfusion $(0.2 \mathrm{psi}, 30 \mathrm{~s})$ from a pipette $15-100 \mu \mathrm{m}$ from the cell soma. Medium containing vehicle only did not alter responses to GABA or S-glutamate. GABA responses ( $\mathrm{KCl}$ recordings) of 6-9 $\mathrm{mV}$ amplitude were evoked following membrane hyperpolarization to -80 to -90 $\mathrm{mV}$, and glutamate responses (KAc recordings) of similar amplitude obtained near resting membrane potential $(-60$ to $-70 \mathrm{mV})$ were used for assessment of drug actions. Data were accepted only if the amino acid responses returned to control levels within 5 min following removal of the drug-containing pipette from the vicinity of the cell under study. Results are expressed as mean \pm standard error of the mean. When KAc recording micropipettes are used, application of GABA to SC neurons produces membrane hyperpolarization and an increase in membrane conductance [11]. Use of KCl-containing recording micropipettes allows chloride ions to enter the cell, changing the equilibrium potential for chloride ions from about $-65 \mathrm{mV}$ to $-20 \mathrm{mV}$, and GABA responses become depolarizing [11].

GABA responses were enhanced $(65.0 \pm 3.0 \%)$ over control by $100 \mathrm{nM}$ diazepam $(n=113$ cells) in a reversible fashion (Fig. 1A1), and responses to S-glutamate were unaffected by $1 \mu \mathrm{M}$ diazepam (responses $98.9 \pm 1.0 \%$ control, 10 cells, Fig. 1A2), confirming previous studies demonstrating concentration-dependent enhancement of GABA responses by BZs in cultured avian and mouse SC and mouse cortical neurons $[2,9,10,20]$. Diazepam $(0.1 \mathrm{nM}-10 \mu \mathrm{M})$ did not alter membrane potential or conductance.

Ro $15-1788$ (100 $\mathrm{nM}$ ) failed to alter GABA responses, while inhibiting (by 28.9 
$\pm 7.0 \%, P<0.01$, Student's $t$-test) enhancement of GABA responses by $100 \mathrm{nM}$ diazepam (Fig. 2). At $1 \mu$ M, Ro $15-1788$ reversibly enhanced GABA responses by more than $10 \%$ in 14 of 15 cells studied (mean enhancement $21.9 \pm 2.9 \%, P<0.001$ from control; Figs. 1A3, 1B), but did not alter S-glutamate responses (responses $101.6 \pm 0.6 \%$ control, 6 cells; Fig. 1A4). At $1 \mu \mathrm{M}$, Ro 15-1788 also abolished further enhancement of responses by diazepam (Figs. 1B and 2). Similar effects on basal and diazepam-enhanced GABA responses were seen with $10 \mu \mathrm{M}$ Ro 15-1788, and at this concentration the enhancement of GABA responses by Ro 15-1788 was no greater than that observed at $1 \mu \mathrm{M}$ Ro $15-1788$ (Fig. 2). This would suggest that

\section{A1. GABA}

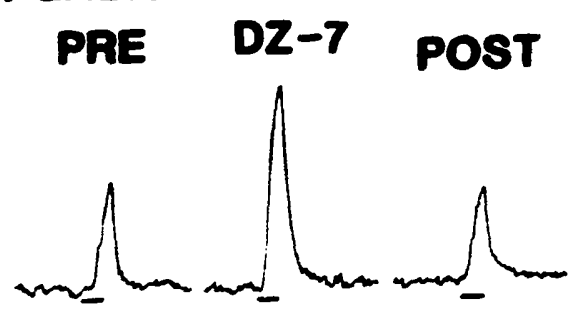

B. GABA

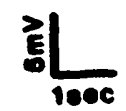

PRE RO-6 $\underset{D Z-7}{\text { RO-6 POST }}$

A2. GLU
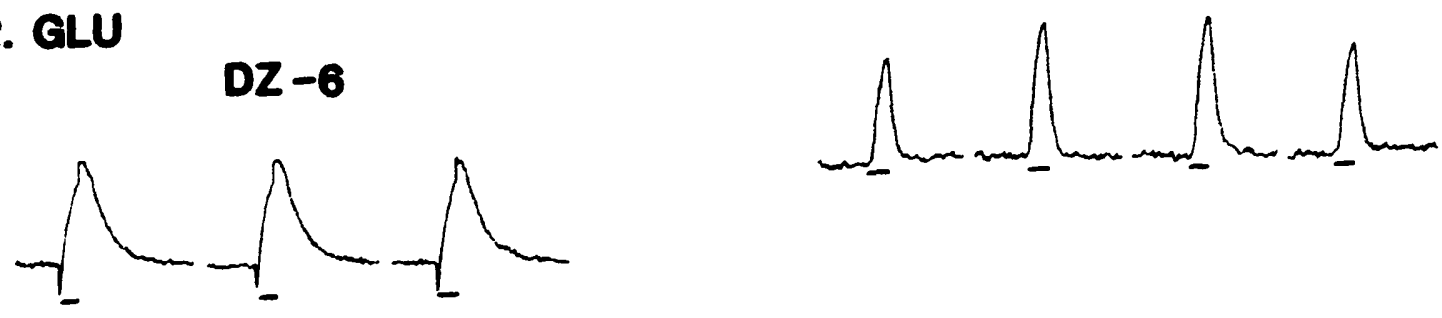

A3. GABA

$$
\text { Ro-6 }
$$

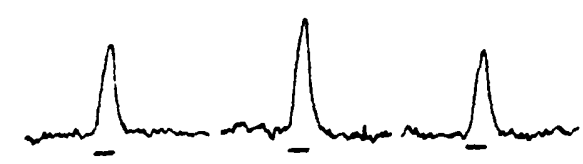

A4. GLU

Ro-6

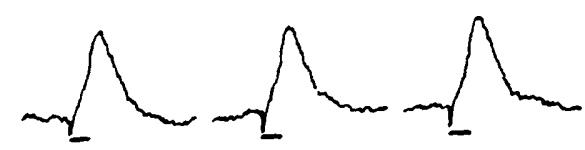

C1. GABA

\section{EtBCC-5}

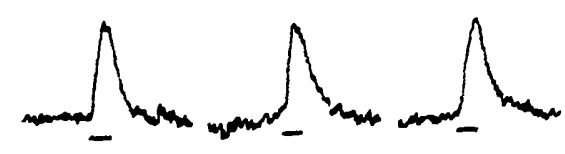

C2. GABA
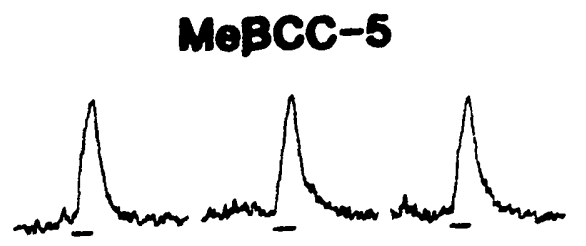

Fig. 1. Effects of diazepam and Ro 15-1788 on amino acid responses of mouse SC neurons in culture. A1: effects of diazepam $\left(10^{-7} \mathrm{M}\right)$ on GABA responses (membrane potential $(\mathrm{MP})=-80 \mathrm{mV}$ ). A2: effects of diazepam $\left(10^{-6} \mathrm{M}\right)$ on glutamate responses $(\mathrm{MP}=-71 \mathrm{mV}) . \mathrm{A3}, 4:$ effects of Ro 15-1788 $\left(10^{-6}\right.$ $\mathrm{M})$ on GABA $(\mathrm{MP}=-75 \mathrm{mV})$ and glutamate $(\mathrm{MP}=-75 \mathrm{mV})$ responses. B: blockade of diazepam $(100 \mathrm{nM})$ enhancement of GABA responses by Ro $15-1788\left(10^{-6} \mathrm{M}\right)(\mathrm{MP}=-80 \mathrm{mV})$. C: effects of $\beta C C M e\left(10^{-5} \mathrm{M}, \mathrm{Cl}, \mathrm{MP}=-90 \mathrm{mV}\right)$ and $\beta C C E t\left(10^{-5} \mathrm{M}, \mathrm{C} 2, \mathrm{MP}=-90 \mathrm{mV}\right)$ on $\mathrm{GABA}$ responses. 
the agonistic action of Ro 15-1788 is indeed 'partial' in nature. Ro 15-1788 (0.1 $\mu \mathrm{M}-10 \mu \mathrm{M})$ did not alter membrane potential or conductance. Enhancement of GABA but not S-glutamate responses with absence of direct membrane actions suggests some selectivity in the effects of these BZs. In contrast, another anticonvulsant, phenobarbital, has been shown to inhibit S-glutamate responses and to produce membrane hyperpolarization by increasing chloride conductance, a GABAmimetic action [10]. Other BZ antagonists $\beta$-carboline-3-carboxylic acid methyl ester $(\beta C C M e)$ and the ethyl ester $(\beta C C E t)$ [7, 12] failed to affect GABA responses at $10 \mu \mathrm{M}$ (Fig. $1 \mathrm{Cl}, 1 \mathrm{C} 2)(\beta C \mathrm{CMe}$ GABA responses $106.4 \pm 3.4 \%$ control, 6 cells; $\beta C C E t$ GABA responses $101.9 \pm 3.9 \%$ control, 8 cells). Thus, not all compounds with $B Z$ antagonist activity exhibit agonist activity at high concentrations.

Ro 15-1788 has been demonstrated to block diazepam enhancement of GABA effects in cat $S C$ in vivo and isolated rat superior cervical ganglion [12, 13]. In the latter preparation very high Ro 15-1788 concentrations (167 $\mu \mathrm{M}$ and greater) enhanced GABA depolarization by approximately $20 \%$ [12].

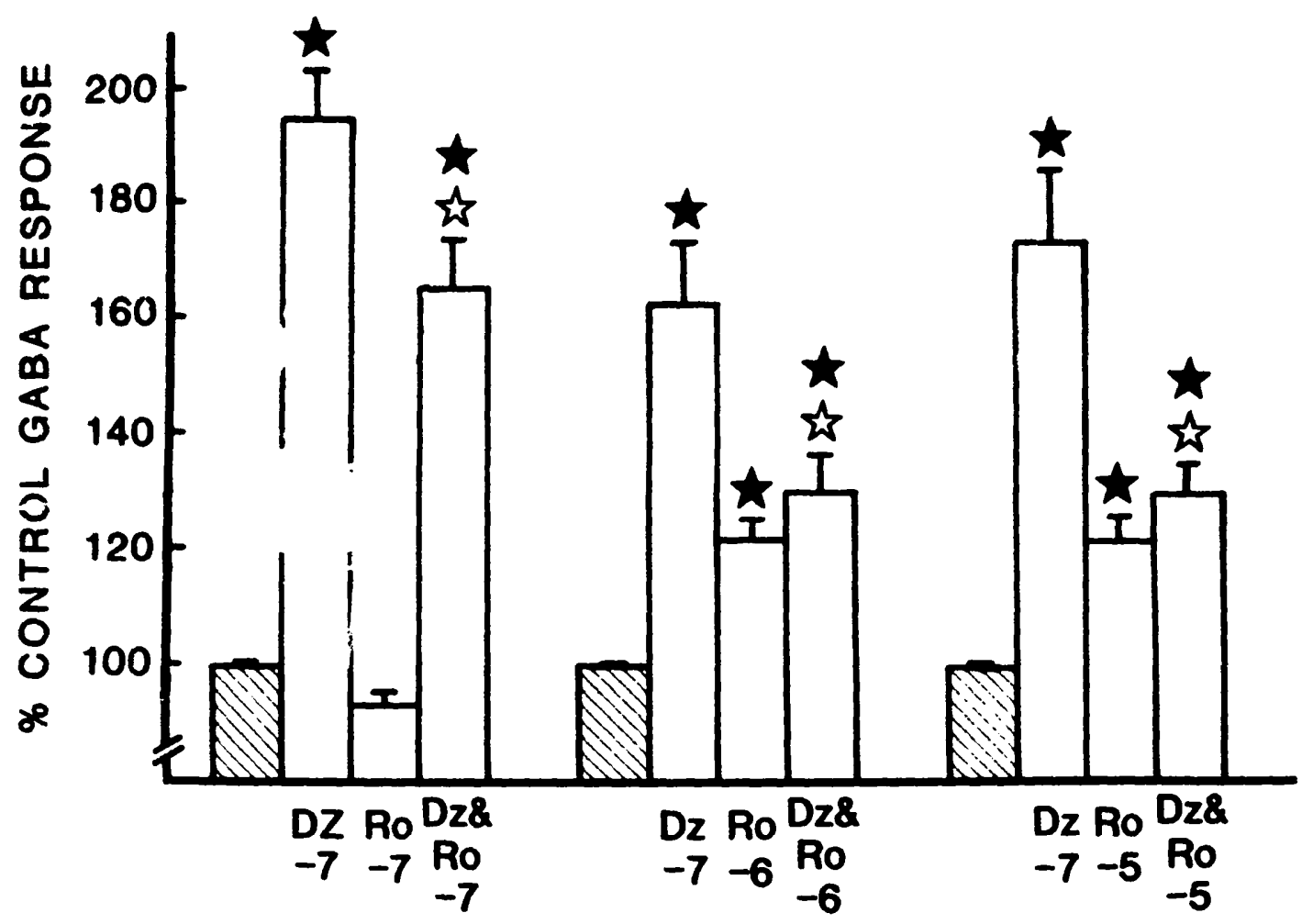

Fig. 2. Enhancement of GABA responses by diazepam and Ro 15-1788. Data shown are from 5-15 cells for each drug or combination. The effects of $100 \mathrm{nM}$ diazepam, the particular Ro 15-1788 concentration studied and the Ro 15-1788-diazepam combination were examined on each cell studied, with 2-3 cycles of application of each drug or combination. By Student's $t$-test: empty stars $P<0.02$, significant difference from $100 \mathrm{nM}$ diazepam; filled stars $P<0.01$, significant difference from vehicle alone $(0.1 \%$ dimethylsulfoxide in buffer, hatched bars). Drug concentrations shown on the figure are logarithm molar. 
Neurochemical studies have shown a potent antagonism of diazepam-enhanced GABA binding by Ro $15-1788\left(\mathrm{IC}_{50}=5 \mathrm{nM}\right)$ but have not revealed enhancement of GABA binding $[8,17]$. These assays were performed at $2^{\circ} \mathrm{C}$; since the potency of diazepam as an enhancer of GABA binding increases severalfold at $25^{\circ} \mathrm{C}$ [16], it may be possible that high concentrations of Ro 15-1788 would enhance GABA binding upon assay at physiological temperature.

A recent study [7] has examined the relationship between in vivo receptor occupancy by various BZ receptor ligands and their activity against audiogenic seizures in DBA/ 2 mice. Ro 15-1788, but not $\beta C C M e$ or $\beta C C E t$, was found to have anticonvulsant activity. Further, the doses required for the anticonvulsant activity of Ro 15-1788 were some 150-fold higher than for diazepam. Whereas classical BZ agonists had anticonvulsant activity in this model at low receptor occupancy $(<10 \%)$, almost complete occupancy by Ro 15-1788 was required for its anticonvulsant activity. These results, together with the differing concentration-dependencies of GABA enhancement by diazepam and Ro 15-1788, suggest that different levels of receptor occupancy by the two compounds may be required for the enhancement of GABA receptor affinity.

The partial agonist activity of Ro 15-1788 at high doses or concentrations should be taken into account when the compound is used experimentally and clinically. Ro 15-1788 has been proposed as combination therapy to counteract the sedative effects of the antischistosomal BZ 3-methylclonazepam [6] and may be useful in BZ overdose cases. While Ro 15-1788 lacks sedative activity in man at doses of $600 \mathrm{mg} /$ day and lower [4], higher doses could possibly cause sedation or tolerance.

We are grateful to Hoffmann-LaRoche, Nutley, NJ, for gifts of Ro 15-1788 and diazepam. J.H.S. is a recipient of an award from the Rotary Foundation of Rotary International, and the research was supported by NIH Grants NS 19692 and NS 00408 to R.L.M.

1 Albertson, T.E., Bowyer, J.F. and Paule, M.G., Modification of the anticonvulsant efficacy of diazepam by Ro 15-1788 in the kindled amygdaloid seizure model, Life Sci., 31 (1982) 1597-1601.

2 Choi, D.W., Farb, D.H. and Fischbach, G.D., Chlordiazepoxide selectively augments GABA action in spinal cord cell cultures, Nature (Lond.), 269 (1977) 342-344.

3 Dantzer, R. and Perio, A., Behavioural evidence for partial agonist properties of Ro 15-1788. a benzodiazepine receptor antagonist, Europ. J. Pharmacol., 81 (1982) 655-658.

4 Darragh, A., Lambe, R., O'Boyle, C., Kenny, M. and Brick, I., Absence of central effects in man of the benzodiazepine antagonist Ro 15-1788, Psychopharmacol., 80 (1983) 192-195.

5 Greckseh, G., Prado de Carvalho, L., Venault, P., Chapouthier, G. and Rossier, J., Convulsions induced by submaximal dose of pentylenetetrazol in mice are antagonised by the benzodiazepine antagonist Ro 15-1788, Life Sci., 32 (1983) 2579-2584.

6 Hunkeler, W., Mohler, M., Pieri, L., Dole, P., Bonetti, E.P., Cumin, R., Schaffner, R. and Haefely, W., Selective antagonists of benzodiazepines, Nature (Lond.), 290 (1981) 51.4-516.

7 Jensen, L.H., Petersen, E.N. and Braestrup, C., Audiogenic seizures in DBA/2 mice discriminate sensitively between low efficacy benzodiazepine receptor agonists and inverse agonists, Life Sci., 33 (1983) 393-399. 
8 Korneyev, A.Y., Benzodiazepines stimulate muscimol receptor binding in an Ro 15-1788 reversible manner, Europ. J. Pharmacol., 90 (1983) 227-230.

9 Macdonald, R.L. and Barker, J.L., Benzodiazepines specifically modulate GABA-mediated postsynaptic inhibition in cultured mammalian neurones, Nature (Lond.), 271 (1978) 563-564.

10 Macdonald, R.L. and Barker, J.L., Enhancement of GABA-mediated postsynaptic inhibition in cultured mammalian spinal neurons: a common mode of anticonvulsant action, Brain Res., 167 (1979) 323-326.

11 Nowak, L.M., Young, A.B. and Macdonald, R.L., GABA and bicuculline actions on mouse spinal cord and cortical neurons in cell culture, Brain Res., 244 (1982) 155-164.

12 Nut:, D.J., Cowen, P.J. and Little, H.J. Unusual interactions of benzodiazepine receptor antagonists, Nature (Lond.), 295 (1982) 436-438.

13 Polc, P., Laurent, J.-P., Scherschlicht, R. and Haefely, W., Electrophysiological studies on the specific benzodiazepine antagonist Ro 15-1788, Naunyn-Schmiedeberg's Arch. Pharmacol., 316 (1981) 317-325.

14 Ransom, B.R., Neale, E., Henkart, M., Bullock, P.N. and Nelson, P.G., Mouse spinal cord cells in culture. I. Morphologic and intrinsic neuronal electrophysiological properties, J. Neurophysiol., 40 (1977) 1132-1150.

15 Robertson, H.A. and Riives, M.L., A benzodiazepine antagonist is an anticonvulsant in an animal model for limbic epilensy, Brain Res., 270 (1983) 380-382.

16 Skerritt, J.H., Chen Chow, S. and Johnston, G.A.R., Differences in the interactions between GABA and benzodiazepine binding sites, Neurosci. Lett., 33 (1982) 173-178.

17 Skerritt, J.H. and Johnston, G.A.R., Enhancement of GABA binding by benzodiazepines and related anxiolytics, Europ. J. Pharmacol., 89 (1983) 193-198.

18 Skerrit, J.H., Johnston, G.A.R. and Chen Chow, S., Interactions of carbamazepine with benz.odiazepine receptors, J. Pharm. Pharmacol., 35 (1983) 464-465.

19 Vellucci, S.V. and Webster, R.A., Is Ro 15-1788 a partial agonist at benzodiazepine receptors? Europ. J. Pharmacol., 90 (1983) 263-268.

20 White, W.F., Dichter, M.A. and Snodgrass, S.R., Benzodiazepine binding and interactions with the GABA receptor complex in living cultures of rat cerebral cortex, Brain Res., 215 (1981) 162-176. 